\title{
The Effect of Social Media Marketing and Brand Image on Choosing Decision of A School of Business in Bandung
}

\author{
Erza Karamang ${ }^{1, *}$
}

\author{
${ }^{1}$ STIE Indonesia Membangun \\ ${ }^{*}$ Corresponding author. Email: missezra99@ gmail.com
}

\begin{abstract}
In the era of digitalisation, the need for social media marketing and brand image in various industries is very important, including in the Higher Education industry. Online marketing efforts and activities are needed to influence prospective students in choosing a School of Business Bandung. Therefore, social media marketing is expected to contribute to the decision making of prospective students, while the brand image is expected to have a significant role in improving the decisions. This study aims to examine the effect of social media marketing and brand image on the decision of students in choosing a School of Business in Bandung. The method used was descriptive and verification research with a sample of 100 students. The sampling technique used was non-probability sampling. For data analysis, the Multiple Linear Regression statistical tool was used with a significance level of 5\% for the T-Test and F-Test. The results of this study indicated that both partial and simultaneous tests showed that social media marketing and brand image variable influenced choosing decision, in which brand image had a greater contribution than social media marketing.
\end{abstract}

Keywords: social media marketing, brand image, decision to choose, School of Business.

\section{INTRODUCTION}

The process of deep learning is a way for humans to develop their potential and expertise. Formal education in Indonesia starts from elementary schools to tertiary levels (strata one, strata two, and three), where universities become one of the efforts to educate the life of the nation and have a role to be a part in overcoming the problems of the human resources quality.

The number of SMA-MA and SMK (high school/ vocational high school) graduates in 2018/2019 was $2,997,421$. By comparing the number of tertiary institutions and the number of high school graduates, there was an increasingly tight competition between existing universities. Table 1 shows the number of universities in West Java Province.
Table 1. Universities in West Java Province

\begin{tabular}{|l|l|l|}
\hline No & \multicolumn{1}{|c|}{ Classification } & \multicolumn{1}{c|}{ Total } \\
\hline 1 & Academy & 92 \\
\hline 2 & Polytechnique & 48 \\
\hline 3 & College & 365 \\
\hline 4 & Institute & 27 \\
\hline 5 & University & 65 \\
\hline 6 & Community Academy & 5 \\
\hline \multicolumn{2}{|l|}{ Total } & 602 Higher Education Institutions \\
\hline
\end{tabular}

$$
\text { Source : [1] }
$$

An increase in new students is good news for every tertiary institution. This indicates that universities with a growing number of students have a good image or credibility in the minds of the public, so that many entrust to continue their education at that tertiary 
institution. As happened in a School of Business in Bandung, which has an increased number of students from year to year as clearly shown in the data Figure 1. The number of students accepted from 2015 to 2019 can be seen in Figure 1.

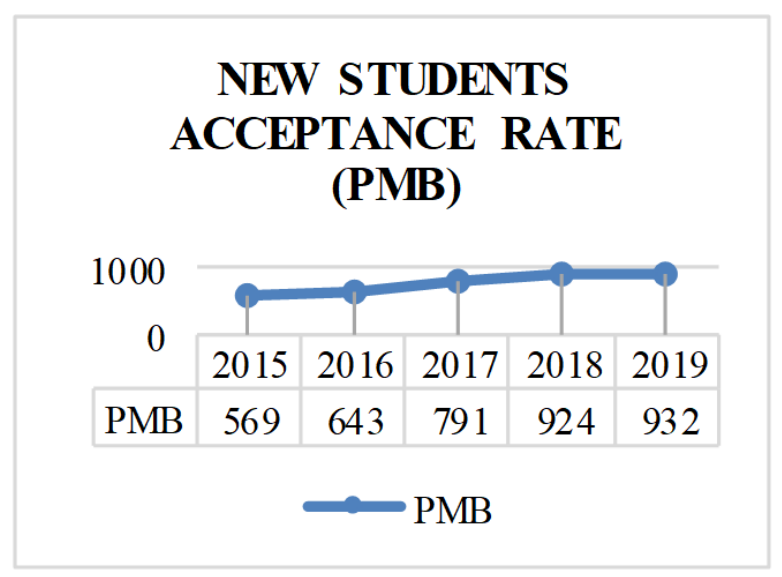

Source: PR of a business school in Bandung

Figure 1. The number of new students accepted at a Business School in Bandung from 2015 to 2019.

Some factors that influence the increase in new student admission are those related to technology. Social media was born thanks to the encouragement of technological development. In this case, social media is used as a tool to approach the community to promote a product or service. In other words, this activity is referred to as social media marketing. Instagram is a social media that is widely used by the community, especially among the youth. This is an opportunity for universities that want to introduce their institutions, so that their presence is better known.

Another factor that can influence purchasing decisions is the brand image owned by universities. Brand image is an image that is formed from the thoughts of individuals in seeing and valuing a brand. The brand image created will affect the actions that will be taken. The creation of a brand image takes a long time, so it will be difficult to change the image of a brand if it has previously developed a negative image. The good or bad of a brand image will affect purchasing decisions. A good brand image will make people unconsciously recommend to choose the brand and vice versa. It is possible that the negative brand image will make people easily spread information that will harm the image of the university.

Thus, the current research aims to see the effect of social media marketing and brand image on choosing decision of a School of Business in Bandung.

\subsection{Social Media Marketing}

Reference [2] states that social media marketing is a form of direct or indirect marketing used to build awareness, recognition, memory, and actions for brands, businesses, products, people, or other entities and is carried out using tools from the social web. Social media is used by social media marketing as a marketing channel, which is one of the means for product marketing.

There are 4 dimensions that serve as variables in measuring the success of social media marketing [2], namely:

- Content creation is content that is created and presented attractively in doing social media marketing. The content created must be as attractive as possible and must represent and characterize a business, so that it can generate trust from the target consumers.

- Content sharing is content that is shared with the social community and can add to a business network, which also adds an online audience and influences sales, depending on how strong the content is towards consumers.

- Connecting is social relationships that connect more people who share the same tastes and interests. Business can be generated even more from a wide network coverage.

- Community building, the social web is a big community consisting of individual online that communicates every individual or group in the world at large.

\subsection{Brand Image}

Brand image is how customers and others view a brand (Aaker in [3]). There are three dimensions used to measure the success of a brand image, namely:

- Recognition

Through recognition, consumers can remember or know the existence of a brand. The recognition of a brand can be reflected by consumers based on past exposure.

- Reputation

In the eyes of consumers, reputation is a status that is high enough for a brand because the brand has a good track record. For example: Trust in a brand in the eyes of consumers

- Affinity

Affinity is the emotional connection that arises between a consumer and a brand. Purchasing decisions and consumer loyalty to the brand rests on affinity. Suitability of the brand with the expectations and pride of the brand can form a 
brand image and make consumers like the products or services offered.

\subsection{Purchasing Decision}

Reference [4] explained that there are 5 processes that should be completed in the purchase decision process, namely:

- Problem Recognition,

- Information Search,

- Alternative Evaluation,

- $\quad$ Purchase Decision, and

- $\quad$ Post Purchase Behavior.

These stages begin long before the purchase is made and have an impact afterward. Reference [4] stated that the AIDA Theory (Attention, Interest, Desire, and Action) is a message that will cause attention, becomes interested, then becomes desire, and produces the final action of the consumer. This theory conveys the quality of the message

\section{METHODS}

According to [5] research method is a scientific way to obtain data with specific purposes and uses. This research used descriptive and verification methods with quantitative approaches. Thus, in conducting this research, a quantitative approach with a survey method was used.

This study included three variables, namely the Decision to Choose at a Business School in Bandung as the dependent variable, Social Media Marketing Instagram, and Brand Image as the independent variable. It is required other elements associated with variables in processing data, and research variables were measured on an ordinal scale.

The sampling technique is a technique to determine the sample that will be used in research [5]. This study used non-probability sampling techniques with sample criteria in this study are students of a Business School in Bandung. The sample size used the Slovin formula. The population size was 3368 students with $\mathrm{e}=0.10$, so the sample size was $97.11 \sim 100$ respondents. The stages of the analysis began with:

Validity Test. According to [6], the results of the study are said to be valid if there are similarities between the data collected and the data that actually occur on the object under the study. The minimum requirement to be considered valid is if the level of significance is $\leq 0.05$.

Reliability Test, to test the reliability of research instruments.
Multiple Linear Regression, this analysis is based on the relationship of one dependent variable with one or more independent variables.

Coefficient of Determination, to determine the effect of independent variables on the dependent variable. The magnitude of the influence of social media marketing and brand image on the decision to choose can be determined by calculating the coefficient of determination with (1).

$\mathrm{Cd}=\mathrm{R} 2 \times 100 \%$

Test $t$ (Partial), which is used to show how much influence one independent or independent variable individually on explaining dependent or dependent variables.

F test (Simultaneous), is carried out to determine the effect of each independent variable on the dependent variable that is tested together. The hypothesis $(\mathrm{Ho})$ to be tested calculates the influence of $X Y \leq 0.05$ sign, which means that there is an influence between the independent variables on the dependent (significance). Conversely, if the alternative hypothesis ( $\mathrm{Ha}$ ) shows that $X Y>0.05$ sign, it means that the variable has no influence between the independent variable on the dependent (not significant).

\section{RESULT AND DISCUSSION}

Figure 2 shows the relationship between variables Social Media Marketing Instagram, Brand Image, and Decision to Choose.

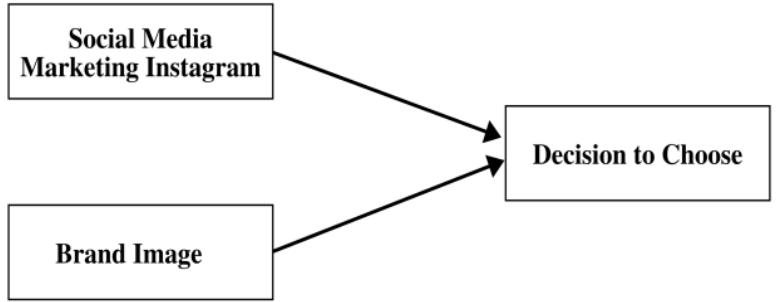

Figure 2. Relationship between variables Social Media Marketing Instagram, Brand Image, and Decision to Choose

\subsection{Test of the Validity and Reliability of Variables}

Based on Table 2, it shows that the results of the SPSS Vers.20 output significance for each statement Instagram social media marketing, brand image, choosing decision $\leq$ sign 0.05 , thus, all Instagram social media marketing statement items, brand image, choosing decision are valid so that the data can be used all for research analysis purposes. 
Table 2. Instrument Validity Social Media Marketing Instagram, Brand Image, Decision to Choose

\begin{tabular}{|l|l|l|l|l|}
\hline No & Item & Sign & \multicolumn{1}{|c|}{ Sign Rate } & Conclusion \\
\hline 1 & SMMI_1 & 0,000 & 0,05 & Valid \\
\hline 2 & SMMI_2 & 0,000 & 0,05 & Valid \\
\hline 3 & SMMI_3 & 0,000 & 0,05 & Valid \\
\hline 4 & SMMI_4 & 0,000 & 0,05 & Valid \\
\hline 5 & SMMI_5 & 0,000 & 0,05 & Valid \\
\hline 6 & SMMI_6 & 0,000 & 0,05 & Valid \\
\hline 7 & SMMI_7 & 0,000 & 0,05 & Valid \\
\hline 8 & BI_1 & 0,000 & 0,05 & Valid \\
\hline 9 & BI_2 & 0,000 & 0,05 & Valid \\
\hline 10 & BI_3 & 0,000 & 0,05 & Valid \\
\hline 11 & BI_4 & 0,000 & 0,05 & Valid \\
\hline 12 & BI_5 & 0,000 & 0,05 & Valid \\
\hline 13 & BI_6 & 0,000 & 0,05 & Valid \\
\hline 14 & CD_1 & 0,000 & 0,05 & Valid \\
\hline 15 & CD_2 & 0,000 & 0,05 & Valid \\
\hline 16 & CD_3 & 0,000 & 0,05 & Valid \\
\hline 17 & CD_4 & 0,000 & 0,05 & Valid \\
\hline
\end{tabular}

Information: SMII=Social Media Marketing Instagram; BI=Brand Image $; \mathrm{CD}=$ Choosing Decision

Source: Data Analysis Result 2020

Based on Table 3, it can be seen that $\alpha$ results for Instagram social brand marketing, brand image, and choosing decision variables $>0,600$. It can be concluded that this research instruments are reliable.

Table 3. Instrument Reliability Social Media Marketing Instagram, Brand Image, Choosing Decision

\begin{tabular}{|l|l|l|l|}
\hline \multicolumn{1}{|c|}{ Variable } & \multicolumn{1}{c|}{$\boldsymbol{\alpha}$ hitung } & \multicolumn{1}{c|}{ A } & Conclusion \\
\hline $\begin{array}{l}\text { Social Media } \\
\text { Marketing Instagram }\end{array}$ & 0,893 & 0,600 & Reliable \\
\hline Brand Image & 0,845 & 0,600 & Reliable \\
\hline Choosing Decision & 0,833 & 0,600 & Reliable \\
\hline
\end{tabular}

Source: Data Analysis Resu

lt 2020

\subsection{Multiple Regression Analysis}

The multiple regression model with one dependent variable is the choosing decision and two independent variables namely Instagram social media marketing, and brand image can be seen in Table 4 .

Table 4. Regression Coefficient

\begin{tabular}{|c|c|c|c|c|c|}
\hline \multicolumn{6}{|c|}{ Coefficients $^{a}$} \\
\hline \multirow[t]{2}{*}{ Model } & \multicolumn{2}{|c|}{$\begin{array}{c}\text { Unstandardized } \\
\text { Coefficients }\end{array}$} & \multirow{2}{*}{\begin{tabular}{|c|}
$\begin{array}{c}\text { Standardized } \\
\text { Coefficients }\end{array}$ \\
Beta \\
\end{tabular}} & \multirow[t]{2}{*}{$t$} & \multirow[t]{2}{*}{ Sig. } \\
\hline & $B$ & Std. Error & & & \\
\hline (Constant) & $-3,532$ & 1,377 & & $-2,564$ &, 012 \\
\hline 1 SMMI &, 195 &, 063 &, 283 & 3,065 &, 003 \\
\hline BI &, 524 &, 084 &, 576 & 6,233 &, 000 \\
\hline
\end{tabular}

Dependent Variable: CD

Source: Data Analysis Result 2020

Based on Table 4, of the two variables tested, the most contributing is the brand image variable, while the social media marketing variable contribution is second after the brand image. This can be seen from the correlation in Table 5, in which brand image percentage is $79.5 \%$, and social media marketing Instagram percentage is $72.8 \%$. The category of influence of the two variables is at the strong level [6].

Table 5. Correlation Table

\begin{tabular}{|c|c|c|c|c|}
\hline \multicolumn{5}{|c|}{ Correlations } \\
\hline & & SMMI & $B I$ & $C D$ \\
\hline \multirow{3}{*}{ SMMI } & Pearson Correlation & 1 & ,771** & ,728** \\
\hline & Sig. (2-tailed) & &, 000 &, 000 \\
\hline & $\mathrm{N}$ & 100 & 100 & 100 \\
\hline \multirow{3}{*}{ BI } & Pearson Correlation &, $771 * *$ & 1 &, $795 * *$ \\
\hline & Sig. (2-tailed) &, 000 & &, 000 \\
\hline & $\mathrm{N}$ & 100 & 100 & 100 \\
\hline \multirow{3}{*}{ KM } & Pearson Correlation & ,728** & $795^{* *}$ & 1 \\
\hline & Sig. (2-tailed) &, 000 &, 000 & \\
\hline & $\mathrm{N}$ & 100 & 100 & 100 \\
\hline
\end{tabular}

Source: Data Analysis Result 2020

From the results of data processing, the regression equation can be made as (2).

$\mathrm{Y}=-3,532+0,195 \mathrm{X} 1+0,524 \mathrm{X} 2+\mathrm{e}$

Notes:

$\mathrm{Y}=$ Choosing Decision

X1 = Social Media Marketing Instagram

$\mathrm{X} 2=$ Brand Image

\subsection{Partial Significance Test (t-Test)}

Based on Table 6, it can be seen that the significance value between the variables that shows the effect of each independent variable on the dependent variable are:

- The significance value of Social Media Marketing Instagram is $0.003 \leq$ where the sign level is 0.05 , meaning $\mathrm{Ho}$ is rejected and $\mathrm{H} 1$ is accepted. In other words, there is an influence of Instagram social media marketing on choosing decision.

- The significance value of brand image is $0,000 \leq$ level of sig 0.05 meaning $\mathrm{Ho}=$ rejected and $\mathrm{H} 1=$ accepted. In other words, there is an influence of brand image on the choosing decision.

Table 6. t-Test Result

\begin{tabular}{|c|c|c|c|c|c|c|}
\hline \multicolumn{7}{|c|}{ Coefficients $^{\mathrm{a}}$} \\
\hline & \multirow[t]{2}{*}{ Model } & \multicolumn{2}{|c|}{$\begin{array}{c}\text { Unstandardized } \\
\text { Coefficients }\end{array}$} & \multirow{2}{*}{\begin{tabular}{|c|}
$\begin{array}{c}\text { Standardized } \\
\text { Coefficients }\end{array}$ \\
Beta
\end{tabular}} & \multirow[t]{2}{*}{$t$} & \multirow[t]{2}{*}{ Sig. } \\
\hline & & $\boldsymbol{B}$ & Std. Error & & & \\
\hline \multirow{3}{*}{1} & (Constant) & $-3,532$ & 1,377 & & $-2,564$ &, 012 \\
\hline & SMMI &, 195 &, 063 &, 283 & 3,065 &, 003 \\
\hline & BI &, 524 &, 084 &, 576 & 6,233 &, 000 \\
\hline
\end{tabular}

Dependent Variable: CDSource: SPSS 20 Data Analysis Result

\subsection{Simultaneous Significance Test (Test F)}

Based on Table 7 , the research significance value obtained is 0,000 , or it means $\leq$ sign level 0.0 . Thus, the hypothesis stating that Instagram social media marketing 
variable, brand image on the choosing decision is statistically accepted (significant).

Table 7. F Test Result

\begin{tabular}{|c|l|l|l|l|l|c|}
\hline \multicolumn{8}{|c|}{ ANOVA $^{\text {Model }}$} & $\begin{array}{c}\text { Sum of } \\
\text { Squares }\end{array}$ & $\boldsymbol{d f}$ & $\begin{array}{c}\text { Mean } \\
\text { Square }\end{array}$ & $\boldsymbol{F}$ & Sig. \\
\hline \multirow{2}{*}{1} & Regression & 589,949 & 2 & 294,975 & 95,947 &, $000^{\mathrm{b}}$ \\
\cline { 2 - 8 } & Residual & 298,211 & 97 & 3,074 & & \\
\cline { 2 - 7 } & Total & 888,160 & 99 & & & \\
\hline
\end{tabular}

Dependent Variable: Choosing Decisiom

Source: SPSS 20 Data Analysis Result

\subsection{Coefficient of Determination}

Based on Table 8, the result obtained by the coefficient of determination (RSquare) is 0.664 , which means that the choosing decision is influenced by changes in Instagram social media marketing and brand image by $66.4 \%$. This shows that there are still other factors by $33.6 \%$ that can increase the decision to choose in addition to Instagram social media marketing and brand image factors.

Table 8. Coefficient of Determination

\begin{tabular}{|l|c|l|l|c|}
\hline \multicolumn{5}{|c|}{ Model Summary } \\
\hline Model & $\boldsymbol{R}$ & $\boldsymbol{R}$ Square & $\begin{array}{c}\text { Adjusted } \boldsymbol{R} \\
\text { Square }\end{array}$ & $\begin{array}{c}\text { Std. Error of the } \\
\text { Estimate }\end{array}$ \\
\hline 1 &, $815^{\mathrm{a}}$ &, 664 &, 657 & 1,753 \\
\hline
\end{tabular}

Predictors: (Constant), BI, SMMI

Source: SPSS 20 Data Analysis Result

\section{CONCLUSION}

\subsection{Conclusions}

Based on the results of SPSS Vers. 20 data processing, the first partially hypothesis testing stated that Instagram Social media marketing significantly influenced the decision to choose the School of Business in Bandung with a significance value of 0.003 $<0.05$.

Based on the results of SPSS Vers. 20 data processing, the second partially hypothesis testing stated that brand image significantly influenced the decision to choose a Business School in Bandung with a significance value of $0,000<0.05$.
Based on the results of SPSS Vers. 20 data processing, the simultaneous hypothesis testing stated that Instagram social media marketing and brand image significantly influenced the decision to choose a Business School in Bandung by $66.4 \%$ and the remaining $33.6 \%$ was influenced by other variables outside of the studied variables.

\subsection{Recommendations}

The School of Business in this research should further maximize the use of Instagram and other social media features to introduce the campus.

The School of Business in this research should be more concerned with brand image and build good relationships with prospective students and the current students, so that they can improve their decision to choose which aims to increase the number of new student admissions.

It is expected that this research can be useful for further research on the same topic and the results of this study can arouse a sense of curiosity for further research by doing interviews or distributing questionnaires to get the maximum results.

\section{REFERENCES}

[1] Pangkalan Data Pendidikan Tinggi, Kementrian Riset, Teknologi, dan Pendidikan Tinggi. [Online]. Available:

https://forlap.risetdikti.go.id/perguruantinggi/home graphp

[2] S. Gunelius, 30-Minute Social Media Marketing. United States: McGraw-Hill Companies, 2011.

[3] A. Ananda, Manajemen Ekuitas Merek: Memanfaatkan Nilai dari Suatu Merek. Jakarta: Spektrum Mitra Utama., 2011.

[4] P. Kotler and K.L. Keller, Marketing Management. Pearson, 2012.

[5] Sugiyono, Metode Penelitian Kuantitatif, Kualitatif, dan R\&D. Bandung: Alfabeta, 2017.

Sugiyono, Statitiska untuk Penelitian. Bandung: Alfabeta, 